\title{
MIDAS
}

Museus e estudos interdisciplinares

$10 \mid 2019$

Varia

\section{Perspetivas sobre a representação das monções no Museu Paulista e no Museu Republicano de Itu}

Perspectives on the representation of monsoons at the Museu Paulista and Museu Republicano de Itu

Maria Aparecida de Menezes Borrego

\section{OpenEdition}

\section{Journals}

\section{Edição electrónica}

URL: http://journals.openedition.org/midas/1784

DOI: $10.4000 /$ midas. 1784

ISSN: 2182-9543

\section{Editora:}

Alice Semedo, Paulo Simões Rodrigues, Pedro Casaleiro, Raquel Henriques da Silva, Ana Carvalho

\section{Refêrencia eletrónica}

Maria Aparecida de Menezes Borrego, « Perspetivas sobre a representação das monções no Museu Paulista e no Museu Republicano de Itu », MIDAS [Online], 10 | 2019, posto online no dia 31 maio 2019, consultado no dia 16 junho 2019. URL : http://journals.openedition.org/midas/1784 ; DOI : 10.4000/ midas. 1784

Este documento foi criado de forma automática no dia 16 Junho 2019.

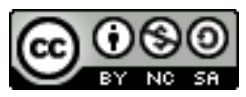

Midas is licensed under a Creative Commons Attribution-NonCommercial-ShareAlike 3.0 International License 


\title{
Perspetivas sobre a representação das monções no Museu Paulista e no Museu Republicano de Itu
}

\author{
Perspectives on the representation of monsoons at the Museu Paulista and \\ Museu Republicano de Itu
}

Maria Aparecida de Menezes Borrego

\section{NOTA DO EDITOR}

Artigo recebido a 29.06.2018

Aprovado para publicação a 03.04.2019

\section{Introdução}

1 Criado por decreto-lei de 1894, o Museu Paulista é o museu público mais antigo da cidade de São Paulo (Brasil) e é popularmente conhecido como Museu do Ipiranga desde que passou a funcionar no bairro do Ipiranga em $1895 .{ }^{1}$ Dedicado ao estudo da história natural, mas desde sempre um marco representativo da Independência do Brasil, o Museu Paulista guardava os traços do modelo enciclopédico predominante nos museus oitocentistas, gradualmente caminhando rumo a uma especialização voltada para a história nacional, sobretudo a partir da direção do historiador Afonso d'Escragnolle Taunay (1876-1958), com sucessivas transferências de acervos para diferentes instituições.

2 Afonso d'Escragnolle Taunay foi nomeado diretor do Museu Paulista em 1917 com a incumbência de realizar os preparativos para o centenário da Independência do Brasil, a ser comemorado em 1922. Para a celebração da efeméride tornou-se imperativo contar a história da nação, através de uma narrativa que explicasse o Brasil como uma unidade 
territorial e simbólica a partir da cidade de São Paulo. Para tanto, o passado colonial paulista fora efusivamente recriado em várias salas expositivas, através da encomenda de pinturas (Brefe 2005).

3 Ao montar as salas dedicadas à temática das monções - expedições fluviais ativas durante o século XVIII e início do séc. XIX - Afonso d'Escragnolle Taunay recorreu às obras de artistas do século XIX, sobretudo as de Hercule Florence (1804-1879) e de Aimé-Adrien Taunay (1803-1828), produzidas no decurso da expedição Langsdorff, entre 1825 e 1829, face à escassa iconografia monçoeira existente. Desta forma, Afonso d'Escragnolle Taunay acabou não só por obscurecer alguns aspetos da expedição Langsdorff retratados pelos ilustradores científicos, mas também criou a discutível associação entre monções e bandeirantes ${ }^{2}$, cujas personagens, roteiros e objetivos eram distintos.

4 Se tal associação foi já analisada com base na narrativa visual da sala A-9, inaugurada em 1929 no Museu Paulista (Pardim 2005; Hessel 2006), a nova montagem consagrada à memória das monções realizada na sala B-4 do museu, em 1944, e a azulejaria sobre esta temática na entrada do Museu Republicano de Itu não foram ainda objeto de uma reflexão de conjunto, análise que este artigo visa explorar e aprofundar. ${ }^{3}$

\section{A construção do mito bandeirante e o Museu Paulista}

5 Quando se pensa no passado colonial de São Paulo, em geral o enfoque dirige-se para o século XVII, quando os bandeirantes desbravaram os sertões, apresaram indígenas e, no final da centúria, descobriram as Minas Gerais. Após este período, as informações são lacunares sobre as atividades económicas desenvolvidas pela população e a articulação da cidade de São Paulo com as então recém-descobertas áreas mineradoras de Cuiabá (1718) e de Goiás (1725) por meio de transações comerciais. A região paulista só retornaria à cena com a chegada do português Luis Antonio de Sousa Botelho Mourão (1722-1798), o 4. ${ }^{\circ}$ Morgado de Mateus, em 1765, e com o estabelecimento de novas diretrizes económicas para a capitania.

6 A escassez de conhecimento sobre as dinâmicas socioeconómicas que se desenvolveram na primeira metade do século XVIII paulista deve-se à força de estudos que retrataram a cidade setecentista - e a capitania, em geral - como pobre, pela ausência de produtos agrícolas para exportação; isolada, pela fraca participação no comércio internacional como fornecedora de matéria-prima; e decadente, pelo despovoamento em função do deslocamento de colonos para as regiões auríferas e do declínio do movimento bandeirante (Taunay 1923; Ellis Jr. 1950; Petrone 1968; Canabrava 1972; Prado Jr. 1975). O abastecimento interno, a imigração de portugueses a este associados e os circuitos mercantis coloniais não foram profundamente considerados por não se inserirem no sentido da colonização, embora vozes dissonantes tenham revelado conjunturas bastante distantes das imagens cristalizadas referidas (Holanda 1945; Zemella 1990; Marcílio 1974; Monteiro 1994; Nazzari 2001; Blaj 2002; Kok 2004; Borrego 2010; Silva 2013).

Em sintonia com uma historiografia mais tradicional processou-se a construção do mito bandeirante pela elite paulista nas primeiras décadas do século XX, utilizado como instrumento de legitimação da sua hegemonia no cenário nacional, em que estavam em curso as tensões regionais que desembocariam na revolução de 1930 (Abud 1986; Ferreira 2002; Ferretti 2004). Sendo a memória uma componente fundamental da vida social, a sua construção e controle pelos grupos dominantes tornaram-se-iam estratégicos para o 
reforço da afirmação identitária, como também o foram os esquecimentos e os silêncios por estes orquestrados (Le Goff 1994, 496).

8 As abordagens glorificadoras da figura do bandeirante paulista contribuíram para eclipsar os estudos sobre o contexto setecentista de São Paulo e as suas conexões comerciais com as minas de Cuiabá, em que as monções desempenharam um papel fundamental. Segundo o historiador Sérgio Buarque de Holanda (1902-1982):

[...] o que estimulava agora essas expedições já não era tanto o ânimo aventureiro, mas o lucro certo, que prometia o comércio com esses remotos sertões, distanciados de qualquer recurso, onde os preços atingidos por todos os artigos, até mesmo os de uso indispensável, parecem destinados a compensar abundantemente todos os riscos da viagem. (Holanda 1945, 93)

Diferente das bandeiras, as monções eram expedições fluviais que se realizaram entre Araritaguaba - atual Porto Feliz - (São Paulo) e Cuiabá (Mato Grosso) nos séculos XVIII e inícios do XIX, percorrendo os rios Tietê, Paraná, Pardo, Coxim, Taquari, Paraguai, São Lourenço e Cuiabá. A rota das monções tornou-se regular justamente a partir dos anos de 1720 - e não antes desse período -, com o descobrimento do ouro nos barrancos do rio Coxipó e outros afluentes do rio Cuiabá, e compôs uma rede de "estradas móveis" utilizada para o abastecimento das populações, fundação de vilas, povoamento do território e busca de metais preciosos, situação que perdurou até aos primeiros anos do séc. XIX.

10 A palavra monção tem a sua origem no dialeto árabe e era usada para designar os ventos alternados que determinavam a melhor época para navegar no oceano Índico. Porém, em Portugal e na então América portuguesa, o termo monção referia-se às estações adequadas às viagens, de acordo com o regime das águas. No caso das jornadas para Cuiabá, a época mais favorável situava-se entre fins de março e meados de junho, após o período mais intenso das chuvas e antes das secas. A duração dessas viagens era de cerca de cinco meses, o mesmo período que levavam as viagens de Portugal à Índia (Presotti 2009, 107).

11 A elite político-económica paulista da Primeira República, que sustentou a construção de uma ancestralidade bandeirante vinculada às famílias tradicionais da terra teve no Museu Paulista espaço privilegiado para atuação e um representante na figura de Afonso d'Escragnolle Taunay, diretor da instituição entre 1917 e 1945 (Oliveira Jr. 1994; Brefe 2005; Marins 2007).

12 Formado em engenharia civil em 1900, no Rio de Janeiro, Afonso d'Escragnolle Taunay transferiu-se para a capital paulista, onde se casou no seio de uma família da elite, os Souza Queiroz, e lecionou na Escola Politécnica de São Paulo, entre 1904 e 1910. A sua inserção definitiva no universo da História ocorreu em 1911, quando ingressou simultaneamente nos Institutos Históricos e Geográficos Brasileiro e de São Paulo (Anhezini 2011, 16-17). Admirador dos princípios da escola metódica preconizada pelos historiadores franceses Charles-Victor Langlois (1853-1929) e Charles Seignobos (1854-1942), foi discípulo do historiador Capistrano de Abreu (1853-1927), que o aconselhou a estudar as bandeiras paulistas (Anhezini 2011).

Desde o início da sua administração à frente do Museu Paulista, Afonso d'Escragnolle Taunay empenhou-se em desenvolver um projeto institucional e museológico com vista às comemorações do centenário da Independência em 1922. Para tanto, planeou e executou a decoração interna do edifício-monumento, adquiriu acervos e encomendou pinturas e esculturas que recriassem a história do Brasil a partir de São Paulo - cidade e 
Estado, enquanto lugar material e simbólico da Independência e dos bandeirantes (Mattos 2003; Brefe 2005).

14 Nos últimos anos, a iconografia do Museu Paulista tem sido objeto de pesquisa por vários investigadores. Oliveira e Mattos (1999) refletiram sobre a produção da obra Independência ou Morte e Meneses (1992) analisou o Salão Nobre (1990); Christo (2002) e Marins (2007; 2017) examinaram as representações iconográficas dos bandeirantes; Monteiro (2012) e Lima Jr. (2015; 2018) dedicaram-se à análise das pinturas de Oscar Pereira da Silva (1865[7?] - 1939); Oliveira (2018) estudou as pinturas de Benedito Calixto de Jesus (1853-1927); e Pitta (2013) e Nery (2015) detiveram-se na formação dos acervos artísticos do Museu Paulista e da Pinacoteca do Estado de São Paulo, com destaque para as obras de José Ferraz de Almeida Jr. (1850-1899). Em muitos destes estudos, o período em que Afonso d'Escragnolle Taunay esteve à frente do museu foi abordado em razão das suas sucessivas encomendas de pinturas a artistas nacionais e estrangeiros residentes no Brasil para que produzissem imagens sobre o passado paulista, atendendo à escassez de iconografia colonial.

No Museu Paulista, a sala A-12 - Sala da Antiga Iconographia Paulista, por exemplo, foi consagrada, segundo o próprio diretor, à reprodução, através de pinturas, dos mais antigos documentos iconográficos sobre a capitania e província de São Paulo conhecidos à época e datados do início do século XIX. Como já estudado por Lima e Carvalho (1993), os desenhos originais, muitos deles não coloridos e de tamanhos reduzidos, não permitiriam a eficácia da sua função pedagógica e não possuíam o grau de enobrecimento, respeitabilidade e prestígio que detinha a pintura. Isso poderá explicar as encomendas de Afonso d'Escragnolle Taunay a vários artistas, visando a reprodução de tais documentos iconográficos através da pintura.

\section{Afonso d'Escragnolle Taunay: entre expedições científicas, monções e bandeirantes}

16 A maior parte dos desenhos recolhidos por Afonso d'Escragnolle Taunay, que serviram como matrizes para as pinturas da sala A-12, era da autoria do artista francês Hercule Florence (1804-1879), considerado por Taunay como o «Patriarca da Iconografia Paulista» (Taunay 1937, 79). Natural de Nice, Florence chegara ao Rio de Janeiro em 1824, onde se empregara numa casa de negócio e depois trabalhou numa livraria e tipografia. Atraído pelo anúncio de jornal do barão Georg Heinrich von Langsdorff (1774-1852), cônsul da Rússia no Brasil, apresentou-se e foi escolhido como segundo ilustrador da expedição patrocinada pelo czar da Rússia Alexandre I. Esta expedição pretendia mapear a fauna, a flora, os rios e os minerais de regiões quase desconhecidas do Império brasileiro, do Tietê até ao rio Amazonas (Borroul 1900; Florence 1977; Kossoy 2006).

O primeiro ilustrador da expedição Langsdorff era Aimé-Adrien Taunay (1803-1828) que, diferente de Florence, pertencia a uma família de tradição artística. Antes de integrar a expedição Langsdorff, Aimé-Adrien Taunay havia participado na expedição capitaneada pelo geógrafo francês Louis Claude de Saulces de Freycinet (1779-1842) como ilustrador científico, entre 1817 e 1820 (Costa 2007).

Numa viagem que durou de setembro de 1825 a março de 1829, os ilustradores percorreram - juntamente com o barão e naturalista Georg Heinrich von Langsdorff, o zoólogo francês Édouard Ménétries (1802-1861), o botânico alemão Ludwig Riedel 
(1790-1861) e o astrónomo russo Néster Rubtsov (1799-1874) - cerca de $17000 \mathrm{~km}$ até Belém do Pará por caminhos fluviais. Durante a viagem documentaram as suas impressões sobre a paisagem, os índios, o território e a própria expedição científica, através de textos e desenhos. Partindo de Porto Feliz em direção a Mato Grosso, a expedição refez a rota das monções iniciadas 100 anos antes (Costa, Diener e Strauss 1995).

19 Ainda que a expedição tenha tido várias perdas humanas, como o afogamento do pintor Aimé-Adrien Taunay no rio Guaporé, a "febre tropical" tenha afetado muitos membros do grupo e Georg Heinrich von Langsdorff tenha perdido a memória, os manuscritos produzidos e as coleções sobreviveriam, tendo sido remetidos para São Petersburgo, na Rússia. $^{5}$

20 Ao passar pelo Rio de Janeiro em 1829, de regresso da expedição, Hercule Florence deixou as suas anotações diárias, redigidas em francês, com a família de Aimé-Adrien Taunay, que tinha grande interesse em conhecer como decorreram os trabalhos dos quais havia participado o seu finado filho. Além disso, Hercule Florence guardara os apontamentos que lhe serviram de base para retomar as suas anotações em 1837, quando passou a escrever o diário completo sobre a expedição Langsdorff e sobre a sua vida até 1859, cuja publicação se intitulou: L'Ami des Arts Livré à Lui-même. ${ }^{6}$

21 Em 1874, o Visconde de Taunay, Alfredo Maria Adriano d'Escragnolle Taunay (1843-1899), que era sobrinho de Aimé-Adrien Taunay, acabou por encontrar os manuscritos deixados à sua família 45 anos antes por Hercule Florence, que veio a traduzir e publicar no ano seguinte na Revista do Instituto Histórico e Geográfico Brasileiro sob o título de Esboço da Viagem Feita pelo Sr. Langsdorff ao Interior do Brasil, desde setembro de 1825 até março de 1829. Escripto em original francez pelo $2^{\circ}$ desenhista da commissão scientifica Hercules Florence. Traduzido por Alfredo d'Escragnolle Taunay (Taunay 1875). ${ }^{7}$

Segundo Alfredo Taunay, a partir das palavras introdutórias ao Esboço da Viagem.., tão logo esteve com o manuscrito em mãos, escrevera a Hercule Florence, que morava em Campinas, para indagar-lhe sobre a autoria do relato, ao que o artista lhe respondera afirmativamente (Taunay 1875, 338).

23 Tal como os escritos, os desenhos de Hercule Florence tiveram outros destinos que não apenas a Rússia. Muitos permaneceram com o ilustrador e, após a sua morte, ficaram em poder dos seus filhos; outros foram localizados na Biblioteca Nacional de França em 1920 por Alberto Rangel, ${ }^{8}$ correspondente de Afonso d'Escragnolle Taunay em Paris; outros originais ou reproduções - foram dados ao pintor Benedito Calixto de Jesus pelos descendentes de Florence. ${ }^{9}$ Foi, portanto, aos seus próprios familiares, aos herdeiros de Florence e aos amigos, que Afonso d'Escragnolle Taunay recorreu para construir a memória iconográfica das monções.

24 Para Afonso d'Escragnolle Taunay, a história das monções estava associada ao bandeirantismo como se fosse algo contínuo e homogéneo, como evidenciam as suas próprias palavras: «Criara-se o episódio das monções, inserto com o maior relevo nos anaes do bandeirantismo de São Paulo, assumido (sic) ímpar originalidade não só em nossos fastos nacionais como nos do Universo» (Taunay 1981, 17).

A permanência ao longo do século XVIII e a regularidade anual das expedições foram os fatores que concorreram para que Sérgio Buarque de Holanda, na primeira edição da obra Monções, publicada em 1945, distanciasse gradualmente as chamadas monções de povoado da história das bandeiras. Segundo o historiador: 
Não é só o emprego de meios de locomoção diversos, é, também, e principalmente, o complexo de atitudes e comportamentos, determinados por cada um desses meios, o que fará compreender a distinção essencial entre a primitiva bandeira e a monção de povoado. Naquela, os rios constituem, efetivamente, obstáculos à marcha, e as embarcações são apenas o recurso ocasional do sertanista, utilizável onde a marcha se tornou impossível. Nas monções, ao contrário, a navegação, disciplinadora e cerceadora dos movimentos, é que se torna regra geral, e a marcha a pé, ou a cavalo, ou em carruagem (na fazenda de Camapuã, por exemplo), constitui exceção a essa regra. (Holanda 1945, 143)

Com o desenvolvimento das suas pesquisas, Sérgio Buarque de Holanda passou a destacar cada vez mais o papel das atividades mercantis nas expedições fluviais, ${ }^{10}$ tanto que no livro Caminhos e Fronteiras, publicado em 1957, intitulou o capítulo dedicado às monções como "Frotas de comércio" (Holanda 1994: 135-152).

\section{As exposições dedicadas às monções: A-9 (1929) e B-4 (1944)}

27 As expedições fluviais entre Porto Feliz e Cuiabá ganhariam, de facto, proeminência no Museu Paulista com a inauguração, em 1929, da exposição consagrada às monções e a Almeida Jr. (sala A-9) no piso térreo. A sala fora preparada especialmente para receber a tela Partida da Monção (1897), do pintor ituano José Ferraz de Almeida Jr. (1850-1899), cuja tela era proveniente da Pinacoteca do Estado de São Paulo, transferida a pedido de Afonso d'Escragnolle Taunay (Pardim 2005; Hessel 2006; Oliveira 2007).

A sala A-9 apresentava ainda duas obras de Almeida Jr.: São Paulo a Caminho de Damasco (c. 1888) e o retrato de Prudente José de Morais e Barros (1890). A exposição também contava com algumas das pinturas da sala A-12 encomendadas por Afonso d'Escragnolle Taunay. Essas pinturas tinham como tema as expedições fluviais a partir dos desenhos de Hercule Florence e de Aimé-Adrien Taunay, aspeto devidamente mencionado nas respetivas legendas, nomeadamente: Carga das Canoas (1920), A Partida de Porto Feliz (1920-1921) e Encontro de duas Monções no Sertão (1920), do pintor brasileiro Oscar Pereira da Silva (1865-1939), Benção das Canoas (c. 1920) e Pouso no Sertão. Queimada (c. 1920), do pintor italiano Aurelio Zimmermann (1854-1920).

Para além das pinturas, outros objetos completavam o discurso museográfico: o beque de proa de um canoão ${ }^{11}$, âncoras, um caldeirão de bronze e uma ânfora com águas retiradas do rio Tietê colocadas num vaso decorado com três anhumas - ave comum na região monçoeira -, e ainda o cavalete e a caixa de tintas de Almeida Jr. (Taunay 1937, 71).

Ainda que as cenas representadas nas pinturas referidas retratassem momentos da expedição Langsdorff numa fase de decadência das monções - é de notar que as derradeiras expedições de comércio ocorreram na década de 1830 (Silva 2004, 12) - para Afonso d'Escragnolle Taunay as representações pictóricas remetiam para as já desaparecidas e heróicas viagens dos monçoeiros e dos bandeirantes. Segundo Carlos Lima Jr., num estudo minucioso dedicado à recriação do passado de São Paulo nas salas do Museu Paulista, a partir das encomendas de Taunay:

Os desenhos de Florence e o de autoria de Aimé-Adrien Taunay serviriam, assim, para preencher a carência de imagens a respeito daquelas expedições. $O$ desenho minucioso, de caráter científico, detalhado, em que se agrupavam objetos diversos numa só composição, poderia fornecer informações visuais daquelas viagens, das quais, muitas vezes, permaneceram apenas os registros escritos. (Lima Jr. 2018, 20) 
31 Para fazer prevalecer a sua visão histórica, por mais de uma vez Afonso d'Escragnolle Taunay terá sugerido mudanças nas pinturas com relação à reprodução de elementos originais dos documentos. ${ }^{12}$

32 A associação criada por Afonso d'Escragnolle Taunay entre a expedição científica de Hercule Florence do século XIX e as monções do XVIII e destas com as bandeiras fica ainda mais evidente no conjunto da sala de exposição. Referimo-nos concretamente à colocação das telas acima mencionadas ao lado da pintura de João Batista da Costa (1865-1926), Ruínas da Casa e Capella de Antonio Raposo Tavares em Quitaúna (s/d) e dos trabalhos do pintor chileno Henrique Bernardelli (1857-1936), Bandeirante na Selva (s/d) e Missionários Ensinando os Índios (s/d), telas que representam a atuação dos bandeirantes no período colonial.

Em 1939, a sala consagrada às monções e a Almeida Jr. foi desmontada para dar lugar à Galeria Almeida Jr., que viria a ocupar o corredor do peristilo do Museu Paulista que dava acesso à sala A-9 e ao pequeno cómodo contíguo a este. A sala A-9 passou a chamar-se Sala Almeida Jr., e ali permaneceram as seguintes pinturas: Partida da Monção, São Paulo a Caminho de Damasco - afixada no teto - e o retrato de Prudente de Morais.

Quanto às demais pinturas e objetos relacionados com as monções desconhece-se o seu paradeiro no interior do museu até 1944 , quando foi inaugurada outra exposição dedicada às monções (sala B-4). De acordo com a notícia publicada a 24 de março de 1944 no jornal O Estado de S. Paulo, Afonso d'Escragnolle Taunay sublinhava:

$\mathrm{Na}$ sala B-4, do segundo pavimento do palácio do Ipiranga, sala exclusivamente consagrada às monções, há a notar vinte quadros a óleo dos quais cinco de grandes dimensões. São todos relativos à iconografia das navegações fluviais para as terras do centro longínquo, em Mato Grosso, com exceção de duas composições. São os demais reproduções de documentos hoje mais que seculares, datando quase todos de 1826. Representam aspetos diversos da navegação do Tietê, Paraná, Pardo, Paraguai e mais rios do oeste. (Taunay 1944, 6, negrito da autora)

Cabe salientar que no Banco de Dados e Imagens do Museu Paulista as imagens em negativos de vidro das montagens das salas A-9 (1929) e B-4 (1944) são identificadas como se fossem uma só - a inaugurada em 1929 -, e, por essa razão, as fotografias de ambas exposições são datadas da década de $1930 .{ }^{13}$ A montagem dessa sala não foi objeto de estudos anteriores, tanto que o museu não dispõe de informações sobre as datas de algumas das pinturas expostas. Além disso, como vários dos artistas não tiveram grande destaque no cenário artístico nacional, os dados relativos às suas biografias são escassos, faltando nalguns casos as datas de nascimento e de morte. 


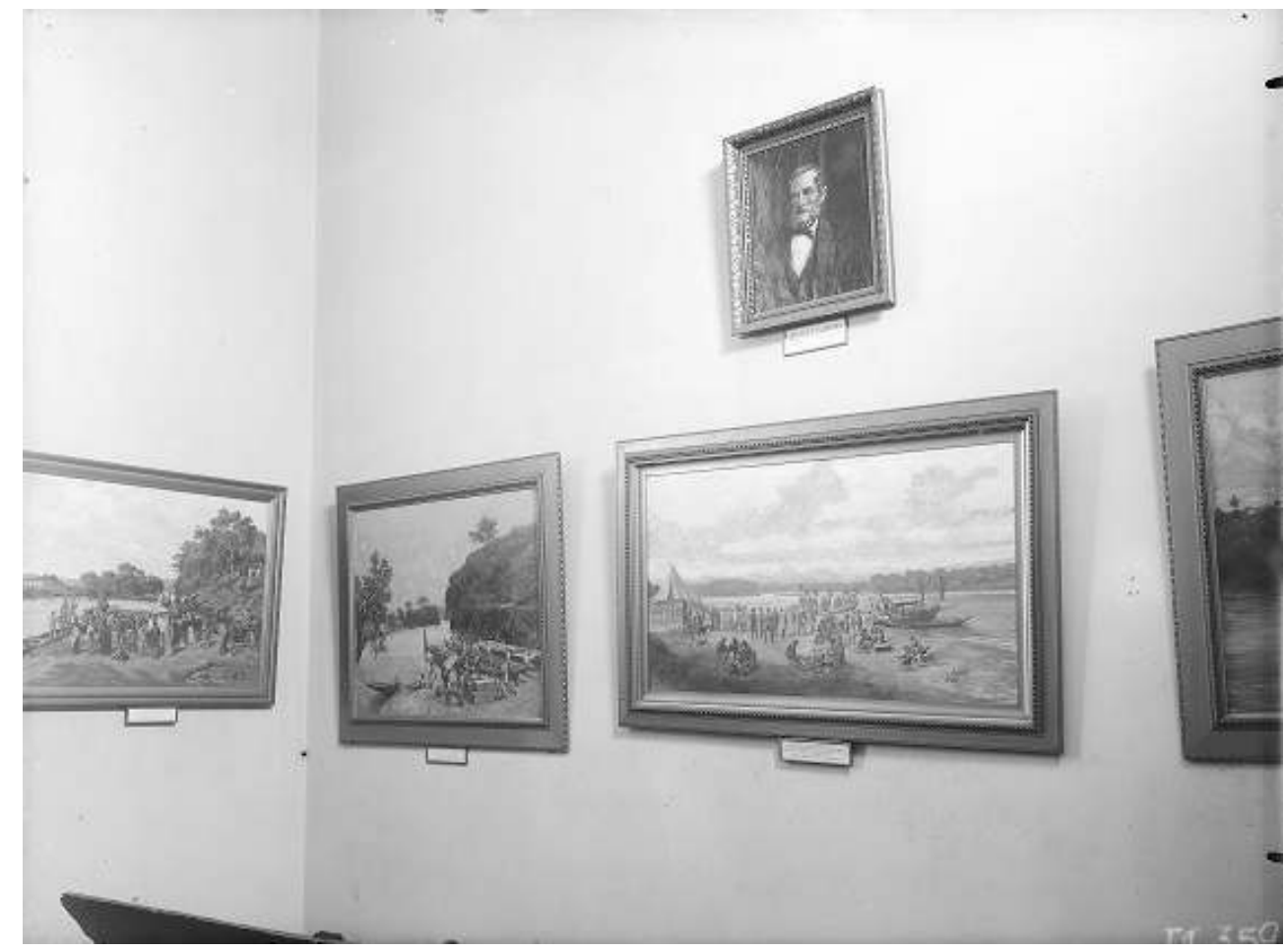

Fig. 1 - Vista parcial da Sala das Monções (B-4), década de 1940, Museu Paulista, São Paulo Fotógrafo não identificado (c) Museu Paulista

A Sala das Monções (B-4) apresentava a seguinte composição (fig. 1): ao alto, em destaque, o retrato de Hercule Florence (s/d), pintado por Oscar Pereira da Silva, em cuja legenda constava: «Hercules Florence Patriarca da Iconografia Paulista (Nice 1804 Campinas 1879) Pintor Oscar Pereira da Silva». Abaixo do retrato, da esquerda para direita, figuravam as pinturas: Benção das Canoas (c. 1920), de Aurelio Zimmermann, Carga das Canoas (1920), Encontro de Duas Monções no Sertão (1920) e A Partida de Porto Feliz, de Oscar Pereira da Silva, da qual só é possível observar na fig. 1 uma pequena fração da tela. Embora estivesse disposta na parede sob a filiação de Hercule Florence, esta última tela teve como matriz o desenho de Aimé-Adrien Taunay, A Partida da Expedição Langsdorff, no Rio Tietê (1825). 


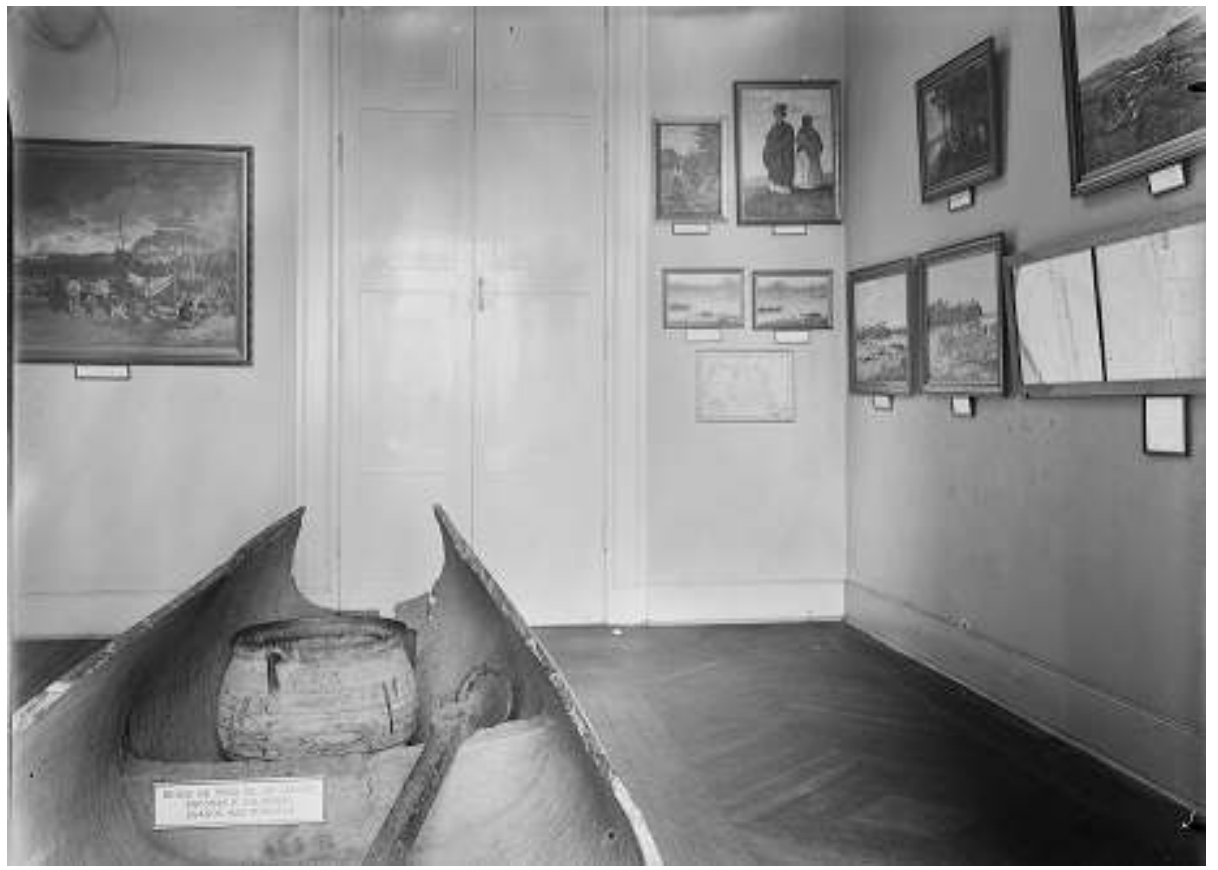

Fig. 2 - Segunda vista parcial da Sala das Monções (B-4), década de 1940, Museu Paulista, São Paulo Fotógrafo não identificado @ Museu Paulista

Como se pode observar na fig. 2, nas duas paredes, separadas por uma porta, apresentavase a pintura Pouso do Sertão. Queimada (c. 1920), de Aurelio Zimmermann; e, da esquerda para a direita: Caboclas do Sertão do Tietê (s/d), do artista belga Adrien Henri Vital Van Emelen (1868-1943), Dama de Porto Feliz com Mucama, 1826 (c. 1922), do italiano Nicolò Petrilli, Canoa Fantasma no Rio Tietê (s/d) e Monstro Fluvial Piracangava (s/d), da pintora brasileira Nair Opromolla Araújo (1914-1982).

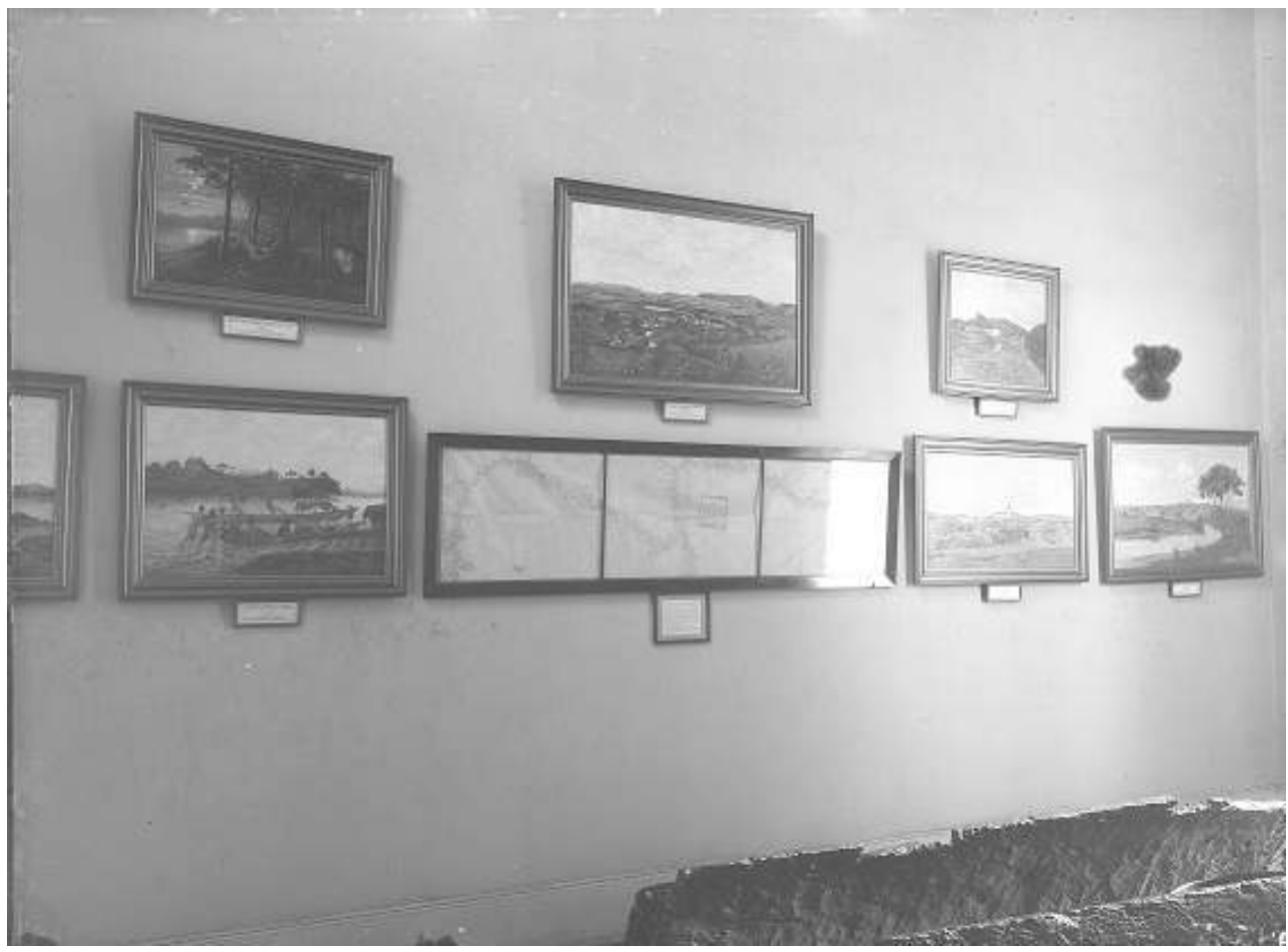

Fig. 3 - Terceira vista parcial da Sala das Monções (B-4), década de 1940, Museu Paulista, São Paulo Fotógrafo não identificado (c) Museu Paulista 

Taunay terá dado instruções minuciosas à pintora Nair Opromolla de Araújo, como se lê na correspondência de 27 de agosto de 1943:

Prezada D. Nair,

Não sei se me fiz compreender a proposta do Bicho Grande do Poço de Pirataraca no Tietê de que falam os cronistas. Imagino o quadro assim:

$[\ldots]$

Num ambiente muito enevoado (como o da Partida da Monção) os homens do canoão em atitude de susto, de pé, com a mão sobre a testa, procurando ver através da bruma olham para a aparição atônitos.

Como representação do monstro pode a Snra. esboçar uma cobra de enorme tamanho muito grossa quase perpendicular sobre o plano das águas em que ela escancarando olhos enormes de acordo com o que (...) Ulrico Schimidel disse segundo lhe contavam os índios viver à margem do Tietê e era imensa.

[...]

Na Sala das Monções do Museu a Snra. encontrará todos os documentos necessários à composição do croquis. ${ }^{15}$

41 A Sala das Monções (B-4) apresentava ainda o mapa do curso dos rios Tietê, Paraná, Pardo, Taquari, elaborado pelo astrónomo e matemático paulista Francisco José Lacerda e Almeida (1753-1798), e outro sobre a rota das monções. No centro da sala figurava o beque de proa, contendo uma âncora e um grande tacho.

Neste contexto faz sentido interrogar o que mudou ou não entre as exposições (Sala A-9 e Sala B-4). 0 que é que estas salas de exposição revelam sobre a memória das monções e a sua representação no discurso museológico, atendendo ao pensamento de Afonso d'Escragnolle Taunay durante o período em que foi diretor do Museu Paulista?

Por um lado, reforça-se a aproximação do referencial da expedição Langsdorff a todas as outras possíveis monções. O retrato de Hercule Florence, com o título de «Patriarca da Iconografia Paulista» na própria legenda e não só na produção escrita de Afonso d'Escragnolle Taunay, evidencia que a sala era consagrada às monções justamente porque a grande maioria das pinturas encomendadas teve os desenhos da expedição Langsdorff como matrizes. Além disso, Afonso d'Escragnolle Taunay teve a preocupação de colocar nas legendas o documento iconográfico que serviu de base a cada pintura. Assim, por exemplo, na legenda da obra Desencalhe de Canoa, 1826, era referido: «Encalhe do 'Chimbó' 
e da 'Perova' (canoões da expedição de Langsdorff) no Tietê (1826) por Zilda Pereira (conforme desenho de Hércules Florence)».

Podemos deduzir que os motivos registados por um ilustrador numa expedição científica durante a década de 1820 foram encarados por Afonso d'Escragnolle Taunay como elementos autênticos de qualquer monção ocorrida ao longo do século XVIII. Exemplos desses episódios são o pouso no sertão vivenciado por Hercule Florence, ${ }^{16} \mathrm{e}$ o encalhe de canoas da expedição Langsdorff, ${ }^{17}$ narrados no seu diário (Florence 2007) que muito dizem sobre os momentos de descanso e das dificuldades de sobrevivência e de navegação, ou seja, sobre as condições materiais do percurso fluvial experimentadas pelos passageiros de qualquer monção.

O facto de as datas da produção dos desenhos-matrizes fazerem parte do título das pinturas encomendadas por Afonso d'Escragnolle Taunay e de este equipará-las a documentos históricos, como fica evidenciado na carta a Nair Opromolla já referida, corrobora a análise pioneira de Lima e Carvalho (1993) sobre as noções de iconografia implícitas na atividade de Afonso d'Escragnolle Taunay. Segundo as historiadoras:

As "recriações" pictóricas dos ambientes da São Paulo colonial são categorizadas por Taunay como documentos iconográficos devido ao fato de terem sido "confecionadas" com base em fontes consideradas "autênticas" pelo historiador e graças à habilidade de seus executores. (Lima e Carvalho 1993, 149)

Por outro lado, a Sala das Monções (B-4) não contou com referências às bandeiras. Se tal constatação poderia fazer supor que Afonso d'Escragnolle Taunay procurava afastar as monções das bandeiras, o próprio artigo escrito por ele na ocasião da inauguração da sala B-4 coloca em dúvida tal suposição. Embora afirmasse que a sala era «exclusivamente consagrada às monç̃̃es», o diretor do museu encerrou a descrição da exposição no jornal com «um tacho que serviu longamente aos bandeirantes» (Taunay 1944, 6). Esta afirmação poderia reforçar a hipótese de que para Taunay, em determinados aspetos, monções e bandeiras se confundissem? É uma hipótese possível, pois o continuum entre os movimentos bandeirante e monçoeiro, sendo este último o derradeiro capítulo daquele, ainda seria explicitado nos anos seguintes na sua monumental História Geral das Bandeiras Paulistas, ao finalizar o $11 .^{\circ}$ tomo, escrito em 1950, com o estudo das monções.

Se tanto na sala A-9 como na sala B-4 os registos de Hercule Florence legitimavam por associação vários aspetos das viagens fluviais anónimas, sem heróis, que o precederam, na construção dos painéis de azulejos no Museu Republicano de Itu, pelo menos uma imagem produzida por Aimé-Adrien Taunay, A Partida da Expedição Langsdorff, no Rio Tietê, seria usada deliberadamente para representar outro acontecimento histórico que a antecedera em décadas, na segunda metade do século XVIII, a monção de povoamento para o Presídio do Iguatemi, localizado no atual Estado do Mato Grosso do Sul.

\section{A representação das monções nos azulejos do Museu Republicano de Itu}

O Museu Republicano de Itu foi inaugurado em 18 de abril de 1923, 50 anos após a Convenção de Itu, ocorrida no mesmo dia no sobrado histórico onde está instalado, então da propriedade de Carlos Vasconcelos de Almeida Prado (1842-1914).

Na década de 1870 existiam vários clubes republicanos espalhados pela Província de São Paulo e a cidade de Itu fora escolhida para sediar a reunião dos afiliados, não por acaso, 
no dia seguinte à inauguração da Estrada de Ferro Ituana, que ligava Itu e Jundiaí, símbolo do progresso económico e da modernidade. Para a inauguração da ferrovia compareceram 133 representantes das agremiações republicanas de 17 cidades paulistas, que estiveram presentes no dia seguinte para o que viria a ser chamado de Convenção de Itu (Zequini 2003).

Em 1923, o Partido Republicano Paulista explorava a comemoração do cinquentenário da Convenção e a criação do Museu Republicano como instrumento de legitimidade histórica para a supremacia do grupo social ligado aos interesses dos grandes cafeicultores de São Paulo, que lhe davam suporte, tal como trabalhavam na glorificação dos bandeirantes (Souza 2003).

51 Washington Luís Pereira de Souza (1869-1957), então presidente do Estado de São Paulo, escolheu Afonso d'Escragnolle Taunay, diretor do Museu Paulista, do qual o Museu Republicano já nasceu como extensão, para supervisionar a intervenção de adaptação dos espaços internos do sobrado ao programa do museu, com base tanto na construção da memória republicana paulista, como na musealização da residência da segunda metade do século XIX (Martins 2012).

Para além da formação da Galeria dos Convencionais, com a encomenda de retratos dos participantes da Convenção de 1873, Afonso d'Escragnolle Taunay idealizou o revestimento das paredes do saguão do Museu Republicano com azulejos que representassem a história local e do Brasil em três séries: «a dos painéis de composição, evocando lances dos fastos ituanos [séculos XVI a XIX], a das reproduções de antigos documentos iconográficos locais e a dos retratos de vários personagens de prol nascidos na velha cidade paulista» (Taunay 1946, 13-14).

Para desenvolver o projeto, Afonso d'Escragnolle Taunay convidou o artista plástico e ceramista Antonio Luiz Gagni (1897-1970). Iniciado em 1942, o trabalho foi considerado concluído em fins de 1945, aquando da aposentadoria compulsória de Taunay aos 70 anos de idade.

Afonso d'Escragnolle Taunay escolheu os temas dos painéis de azulejos e as suas fontes iconográficas, ou então terá inventado imagens para as composições históricas, sobre cujos temas ele não conhecia nenhum registo pictórico, como já comentado para as monções setecentistas em geral ou mesmo para os factos fantásticos das viagens relacionados com monstros e espíritos. Dessa forma, o discurso visual dos azulejos serviria de reforço ao documento textual e evocativo do quadro histórico (Souza 2013). É o que podemos observar nos azulejos que se referem ao período das monções. Dos cinco azulejos dedicados ao itinerário das expedições fluviais e aos acontecimentos vivenciados pelos monçoeiros, quatro terão sido fruto da imaginação de Afonso d'Escragnolle Taunay, criados a partir de narrativas de viagens e de obras historiográficas coloniais lidas por ele, nomeadamente: Os Irmãos João e Lourenço Leme da Silva no Varadouro de Camapuan (1720), Morte Heroica de Miguel Antunes Maciel e Antonio Lobo Defende dos Payaguás a sua Monção (1726), Derrota dos Payaguás no Ataque feito à Monção de Jeronymo Gonçaves Meira (janeiro de 1740), Antonio Pires de Campos, o Pay Pirá, e seus Bororos do Rio das Pedras (1750). 


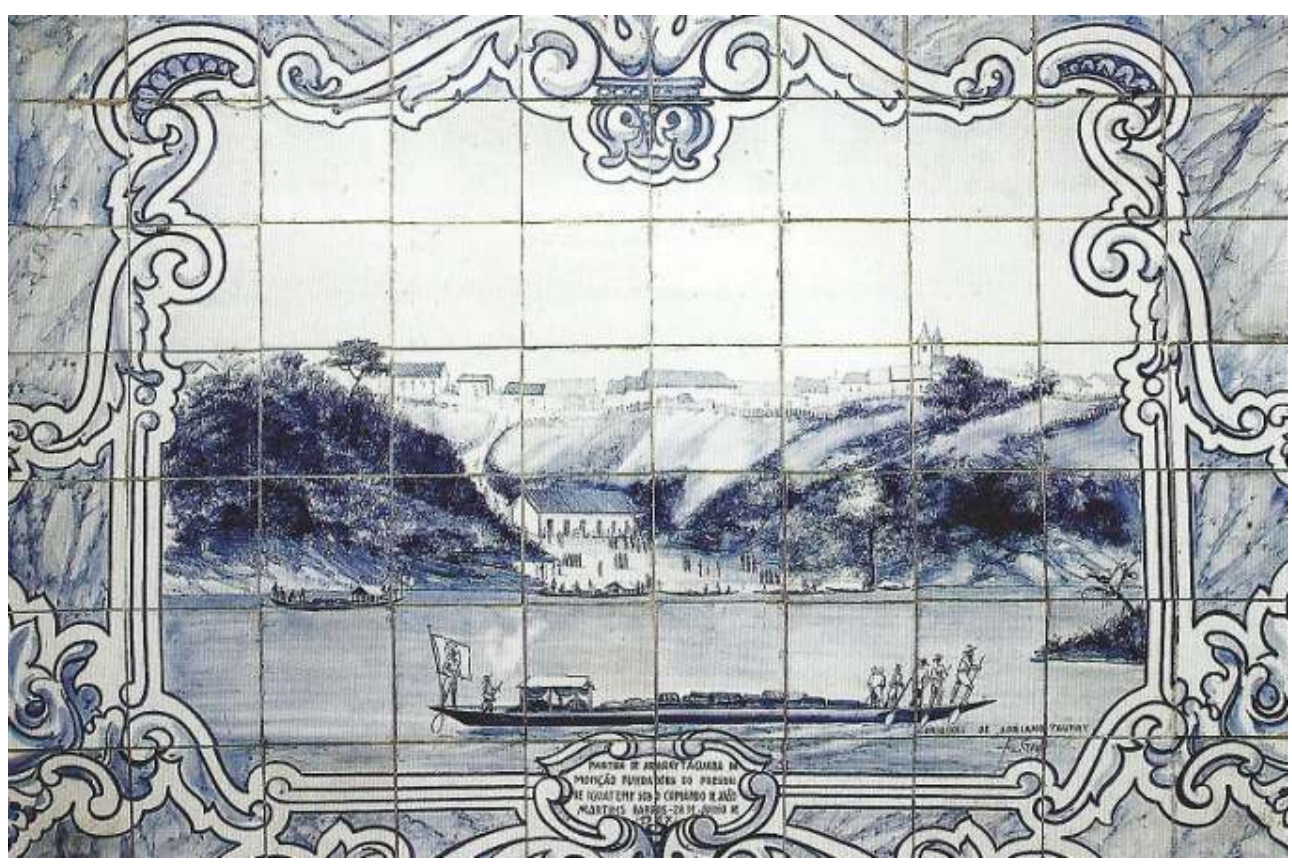

Fig. 4 - Painel de azulejos Partida da Ararytaguaba da Monção Fundadora do Presídio de Iguatemy sob o Comando de João Martins de Barros - 28 de julho de 1767, década de 1940, Antonio Luiz Gagni, 150 x $106 \mathrm{~cm}$

Fotografia de Helio Nobre @ Museu Republicano de Itu/Museu Paulista/Universidade de São Paulo

Como podemos observar num dos azulejos (fig. 4), Afonso d'Escragnolle Taunay terá aproveitado os registos visuais da expedição Langsdorff para representar outros acontecimentos que lhe foram anteriores, relacionados com as monções, mas não com a expedição propriamente dita. É o caso da aguada A Partida da Expedição Langsdorff, no Rio Tietê, de Aimé-Adrien Taunay (fig. 5), que anteriormente servira de matriz para o óleo sobre tela de Oscar Pereira da Silva, A Partida de Porto Feliz, e no Museu Republicado subsidiou o painel de azulejo - Partida de Ararytaguaba da Monção Fundadora do Presídio do Iguatemy sob o Comando de João Martins de Barros - 28 de julho de 1767 (fig. 4). 


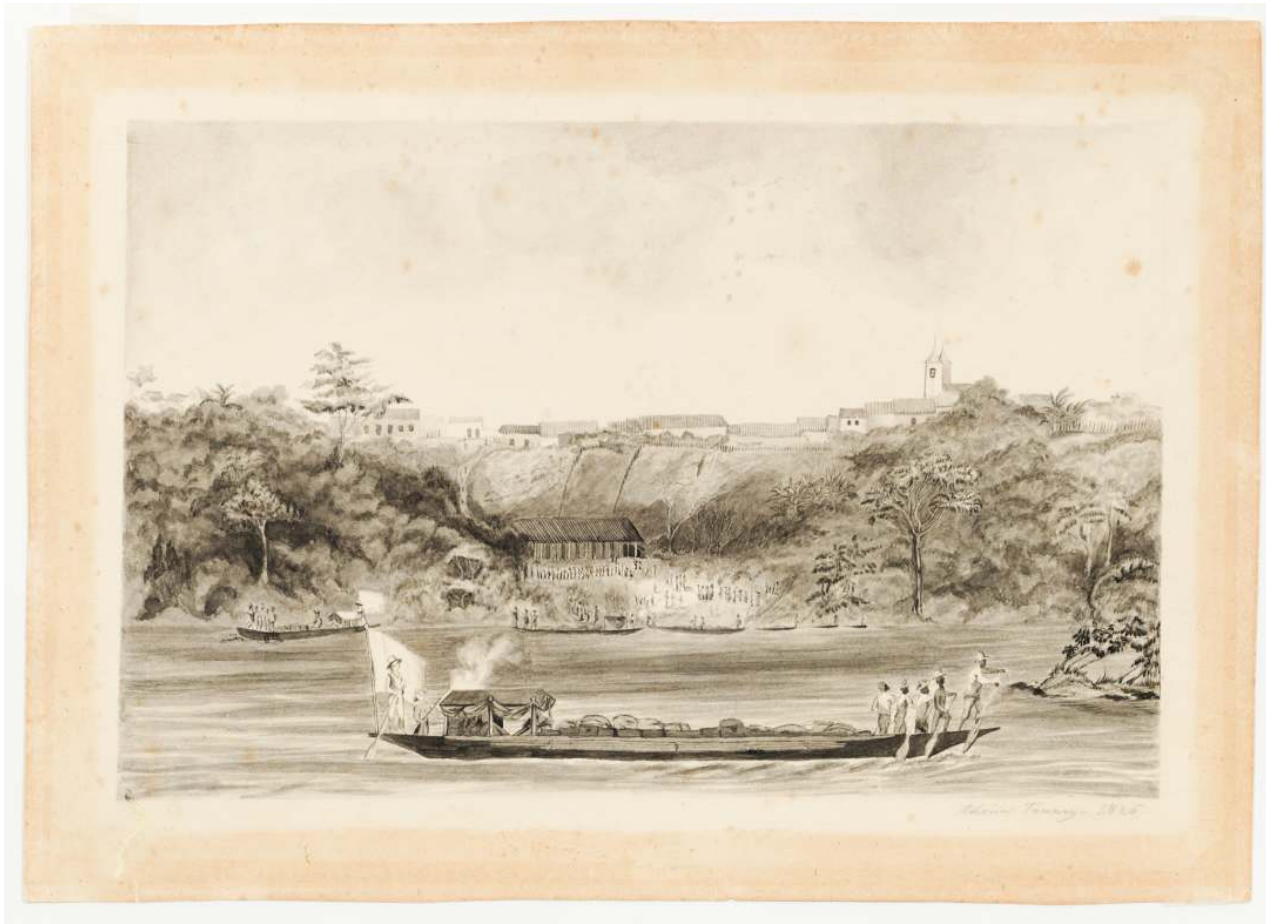

Fig. 5 - A Partida da Expedição Langsdorff, no Rio Tietê (1825), aguada de nanquim sobre papel, 21,0 x 32,2 cm, de Aimé-Adrien Taunay, Coleção Martha e Erico Stickel, Acervo Instituto Moreira Salles

(c) Instituto Moreira Salles, Rio de Janeiro

Se no Museu Paulista Afonso d'Escragnolle Taunay associava de forma dissimulada a expedição Langsdorff com as monções e estas com as bandeiras, por meio do discurso museográfico das salas expositivas, no Museu Republicano tal estratégia ficou evidenciada pelo uso indiscriminado da representação de um facto histórico por outro. Embora Afonso d'Escragnolle Taunay solicitasse ao ceramista Antonio Luiz Gagni que mencionasse no azulejo que a imagem retratada era baseada no original de Aimé-Adrien Taunay, ele não fornecia ao visitante informação sobre o facto do ilustrador ter participado numa expedição científica (1825-1829) - quando o país já era independente - que estava muito distante em termos de objetivos, itinerários e perfil social dos viajantes de uma monção povoadora, ocorrida 60 anos antes, quando o Brasil era ainda colónia de Portugal, com destino a outra localidade que não aquela alcançada pelo ilustrador, seu antepassado.

\section{Conclusão}

Cabe salientar que quando Afonso d'Escragnolle Taunay deixou a direção do Museu Paulista, em 1945, a sala consagrada às monções era a B-4. A sala das monções só voltaria a ocupar a sala A-9 no piso térreo, em 1947, quando a Galeria Almeida Jr. foi desmontada devido à transferência de 19 pinturas para a Pinacoteca do Estado. Nesse ano, Sérgio Buarque de Holanda, então diretor do Museu Paulista, mandou transportar para a sala a Partida da Monção, de Almeida Jr., o beque de proa do canoão, alguns objetos usados pelos paulistas nas suas viagens fluviais e cópias dos quadros de Hercule Florence, reiterando alguns elementos da montagem original de Afonso d'Escragnolle Taunay. Um dos aspetos a investigar futuramente será a identificação desses objetos e quadros. 
58 década de 1960, foi a sala montada por Sérgio Buarque de Holanda, em 1947, e não por Afonso d'Escragnolle Taunay, em 1929, como se pensava até há pouco tempo, uma vez que o Banco de Dados e Imagens do Museu Paulista indicava informações equivocadas sobre as datas das montagens das exposições e os estudos dedicados à representação das monções no Museu Paulista reiteravam essa informação (Pardim 2005; Hessel 2006; Oliveira 2007).

Estes dados evidenciam a relevância dos museus enquanto espaços de produção de conhecimento, potenciando o papel dos acervos como documentos históricos capazes de responderem a várias problematizações. Esta perspetiva não significa eliminar, como purgação das manipulações ideológicas, as construções de memória, as suas alegorias e práticas, mas incorporá-las, como sugere Meneses (1994), como objeto de estudo no campo da documentação e do trabalho reflexivo.

\section{BIBLIOGRAFIA}

Abud, Katia Maria. 1986. "O Sangue Intimorato e as Nobilíssimas Tradições: A Construção de um Símbolo Paulista, o Bandeirante.” Tese de doutoramento em História Social, Universidade de São Paulo.

Anhezini, Karina. 2011. Um Metódico à Brasileira: História da Historiografia de Afonso de Taunay (1911-1939). São Paulo: Editora Unesp.

Blaj, Ilana. 2002. A Trama das Tensões: O Processo de Mercantilização de São Paulo Colonial (1681-1721). São Paulo: Universidade de São Paulo, Humanitas.

Borrego, Maria Aparecida de Menezes, Bernardo Luís Rodrigues de Andrade, Gregório Ceccantini, Milena Godoy-Veiga, Gabriel Bustani Valente, Fillipe Rocha Esteves, e Pedro Henrique Bulla. (no prelo). “Trajetória e Reconstituição Digital de uma Canoa do Museu Paulista." Anais do Museu Paulista. História e Cultura Material.

Borrego, Maria Aparecida de Menezes. 2010. A Teia Mercantil: Negócios e Poderes em São Paulo colonial (1711-1765). São Paulo: Alameda.

Borroul, Estevão Leão. 1900. Hercules Florence (1804-1879): Ensaio Histórico-Literário. São Paulo: Typ. Andrade, Mello.

Brefe, Ana Cláudia. 2005. Museu Paulista: Affonso de Taunay e a Memória Nacional 1917-1945. São Paulo: Museu Paulista, Universidade de São Paulo.

Canabrava, Alice P. 1972. "Uma Economia de Decadência: Os Níveis de Riqueza na Capitania de São Paulo, 1765/67.” Revista Brasileira de Economia 26 (4): 95-123.

Christo, Maraliz de Castro Vieira. 2002. "Bandeirantes na Contramão da História: Um Estudo Iconográfico.” Projeto História 24: 307-335.

Chur, L. A., ed. 1981. A Expedição Científica de G.I. Langsdorff ao Brasil, 1821-1829: Catálogo Completo do Material Existente nos Arquivos da União Soviética. Brasília: Ministério da Educação e Cultura, Secretaria do Patrimônio Histórico e Artístico Nacional, Fundação Nacional Pró-Memória. 
Costa, Maria de Fátima G., Pablo Diener, e Dieter Strauss. 1995. O Brasil de Hoje no Espelho do Século XIX. Artistas Alemães e Brasileiros Refazem a Expedição Langsdorff. São Paulo: Estação Liberdade.

Costa, Maria de Fátima. 2007. “Aimé-Adrien Taunay: Um Artista Romântico no Interior de uma Expedição Científica.” Fênix - Revista de História e Estudos Culturais 4 (4): 1-17.

Ellis Jr., Alfredo. 1950. A Economia Paulista no Século XVIII: Ciclo do Muar, Ciclo do Açúcar. São Paulo: Academia Paulista de Letras.

Ferreira, Antonio Celso. 2002. A Epopéia Bandeirante: Letrados, Instituições, Invenção Histórica (1870-1940). São Paulo: Editora UNESP.

Ferretti, Danilo José Zioni. 2004. “A Construção da Paulistanidade: Identidade, Historiografia e Política em São Paulo (1856-1930).” Tese de doutoramento em História Social, Universidade de São Paulo.

Florence, Hercules. 1977. Viagem Fluvial do Tietê ao Amazonas pelas Províncias Brasileiras de São Paulo, Mato Grosso e Grão-Pará (1825-1829). Tradução de Francisco Álvares Machado e Vasconcellos Florence. São Paulo: Museu de Arte de São Paulo Assis Chateaubriand.

Florence, Hercules. 2007. Viagem Fluvial do Tietê ao Amazonas de 1825 a 1829. Tradução do Visconde de Taunay. Brasília: Senado Federal.

Hessel, Rodolfo. 2006. “Iconografia Monçoeira: Imagens e Ideologia.” Dissertação de mestrado em História, Pontifícia Universidade Católica de São Paulo.

Holanda, Sérgio Buarque de. (1957) 1994. Caminhos e Fronteiras. 3. ed. São Paulo: Companhia das Letras.

Holanda, Sérgio Buarque de. 1945. Monções. Rio de Janeiro: Casa do Estudante do Brasil. Jesus, Benedito Calixto de. 1920. [Correspondência entre Benedito Calixto de Jesus e Afonso Taunay]. Arquivo Permanente do Museu Paulista/Fundo Museu Paulista: Série Correspondências, pasta 112. Correspondência de 10 de agosto de 1920.

Kok, Glória. 2004. O Sertão Itinerante: Expedições da Capitania de São Paulo no Século XVIII. São Paulo: Hucitec.

Komissarov, Boris N. 2010. “Langsdorff: Com o Brasil, para Sempre.” In Expedição Langsdorff [catálogo da exposição], 14-35. Rio de Janeiro: Centro Cultural Banco do Brasil. https:// www.bb.com.br/docs/pub/inst/dwn/Langsdorff.pdf

Kossoy, Boris. 2006. Hercule Florence: A Descoberta Isolada da Fotografia no Brasil. 3. ed. São Paulo: Edusp.

Le Goff, Jacques. 1994. História e Memória. Campinas: Editora da Unicamp.

Lima Jr., Carlos Rogério. 2015. “Um Artista às Margens do Ipiranga: Oscar Pereira da Silva, o Museu Paulista e a Reelaboração do Passado Colonial.” Dissertação de mestrado em Estudos Brasileiros, Universidade de São Paulo.

Lima Jr., Carlos Rogério. 2018. "Da Pena ao Pincel: O Passado Paulista (Re)criado nas Encomendas de Afonso Taunay a Oscar Pereira da Silva." Anais do Museu Paulista: História e Cultura Material vol. 26: $1-40$.

Lima, Solange Ferraz de, e Vânia Carneiro de Carvalho. 1993. "São Paulo Antigo, uma Encomenda da Modernidade: As Fotografias de Militão nas Pinturas do Museu Paulista." Anais do Museu Paulista. História e Cultura Material 1 (1): 147-178. 
Marcílio, Maria Luiza. 1974. A Cidade de São Paulo. Povoamento e População, 1750-1850. São Paulo: Pioneira.

Marins, Paulo César Garcez. 2007. "Nas Matas com Pose de Reis: A Representação de Bandeirantes e a Tradição da Retratística Monárquica Europeia.” Revista IEB 44: 77-104.

Marins, Paulo César Garcez. 2017. “O Museu da Paz: Sobre a Pintura Histórica no Museu Paulista Durante a Gestão Taunay." In O Museu Paulista e a Gestão de Afonso Taunay: Escrita da História e Historiografia, Séculos XIX e XX, organizado por Cecília Helena de Salles Oliveira, 159-181. São Paulo: Museu Paulista da Universidade de São Paulo.

Martins, Mariana Esteves. 2012. “A Formação do Museu Republicano Convenção de Itu (1921-1946).” Dissertação de mestrado em História Social, Universidade de São Paulo.

Mattos, Cláudia Valladão de. 2003. "Da Palavra à Imagem. Sobre o Programa Decorativo de Affonso de Taunay para o Museu Paulista." Anais do Museu Paulista: História e Cultura Material 6/7: 123-145.

Meneses, Ulpiano Toledo Bezerra de. 1992. "O Salão Nobre do Museu Paulista e o Teatro da História." In Como Explorar um Museu Histórico, 25-29. São Paulo: Museu Paulista da Universidade de São Paulo.

Meneses, Ulpiano Toledo Bezerra de. 1994. “Do Teatro da Memória ao Laboratório da História: A Exposição Museológica e o Conhecimento Histórico." Anais do Museu Paulista: História e Cultura Material vol. 2 (jan./dez.): 9-42.

Monteiro, John Manuel. 1994. Negros da Terra: Índios e Bandeirantes nas Origens de São Paulo. São Paulo: Companhia das Letras.

Monteiro, Michelli Scapol. 2012. "Fundação de São Paulo, de Oscar Pereira da Silva: Trajetórias de uma Imagem Urbana." Dissertação de mestrado em História e Fundamentos da Arquitetura e do Urbanismo, Universidade de São Paulo.

Nazzari, Muriel. 2001. O Desaparecimento do Dote: Mulheres, Famílias e Mudança Social em São Paulo, Brasil, 1600-1900. São Paulo: Companhia das Letras.

Nery, Pedro. 2015. “Arte, Pátria e Civilização: A Formação dos Acervos Artísticos do Museu Paulista e da Pinacoteca do Estado de São Paulo (1893-1912).” Dissertação de mestrado em Museologia, Universidade de São Paulo.

Oliveira Jr., Paulo Cavalcante de. 1994. “Afonso d'E. Taunay e a Construção da Memória Bandeirante.” Dissertação de mestrado em Historiografia, Universidade Federal do Rio de Janeiro. Oliveira, Cecília Helena de Salles, e Cláudia Valladão de Mattos. 1999. O Brado do Ipiranga. São Paulo: Edusp.

Oliveira, Eduardo Polidori Villa Nova de. 2018. “'Fundação de São Vicente', de Benedito Calixto: Composição, Musealização e Apropriação (1900-1932).” Dissertação de mestrado em Museologia, Universidade de São Paulo.

Oliveira, Marcela Marrafon de. 2007. "Paquequer, São Francisco e Tietê: As Margens dos Rios e a Construção da Nacionalidade.” Dissertação de mestrado em História. Universidade Estadual de Campinas.

Pardim, Sonia Leni Chamon. 2005. "Imagens de um Rio: Um olhar Sobre a Iconografia do Rio Tietê.” Dissertação de mestrado em Artes, Universidade Estadual de Campinas.

Petrone, Maria Thereza Schorer. 1968. A Lavoura Canavieira em São Paulo: Expansão e Declínio (17651851). São Paulo: Difusão Européia do Livro. 
Pitta, Fernanda Mendonça. 2013. “'Um Povo Pacato e Bucólico’: Costume e História na Pintura de Almeida Júnior.” Tese de Doutorado em Artes, Universidade de São Paulo.

Prado Jr., Caio. (1933) 1975. Evolução Política do Brasil e Outros Estudos. 9. a ed. São Paulo: Editôra Brasiliense.

Presotti, Thereza Martha B. 2009. “A Natureza dos Rios nas Notícias Práticas das Minas de Cuiabá: A Trilha das Águas nos Pantanais do Centro da América do Sul.” Textos de História vol. 17 (1): 107-131.

Rangel, Alberto. 1920. [Correspondência entre Alberto Rangel e Afonso Taunay]. Arquivo Permanente do Museu Paulista/Fundo Museu Paulista: Série Correspondências, pasta 112. Correspondência de 13 de setembro de 1920.

Santos, Márcio. 2009. Bandeirantes Paulistas no Sertão do São Francisco: Povoamento e Expansão Pecuária de 1688 a 1734. São Paulo: Edusp.

Silva, Rodrigo. 2013. Sobre Taipas e Textos: Um Estudo Sobre as Narrativas a Respeito da Cidade de São Paulo. São Paulo: Alameda.

Silva, Valderez Antonio da. 2004. "Fantasmas do Rio: Um Estudo sobre a Memória das Monções no Vale do Médio Tietê." Dissertação de mestrado em História, Universidade Estadual de Campinas.

Souza, Jonas Soares de. 2003. “De Casa a Museu: 80 Anos do Museu Republicano ‘Convenção de Itu'." Anais do Museu Paulista: História e Cultura Material vol. 10/11: 213-225.

Souza, Jonas Soares de. 2013. Painéis de Azulejos do Museu Republicano 'Convenção de Itu'. São Paulo: Edusp, Museu Paulista.

Taunay, Afonso d'Escragnolle. 1923. Pedro Taques e seu Tempo (Estudo de uma Personalidade e de uma Epoca). São Paulo: Oficinas do "Diario official".

Taunay, Afonso d'Escragnolle. 1924-1950. História Geral das Bandeiras Paulistas. São Paulo: Museu Paulista, Imprensa Oficial do Estado de São Paulo, 11 vol.

Taunay, Afonso d'Escragnolle. 1937. Guia da Seção Historica do Museu Paulista. São Paulo: Imprensa Official do Estado.

Taunay, Afonso d'Escragnolle. 1943. [Correspondência entre Afonso Taunay e Nair Opromolla de Araújo]. Arquivo Permanente do Museu Paulista/Fundo Museu Paulista: Série Correspondências, pasta 190. Correspondência de 27 de agosto de 1943.

Taunay, Afonso d'Escragnolle. 1944. "Museu Paulista: Abertura de Novas Salas - Recinto Consagrado às Monções - Iconografia das Cidades mais Antigas.” Jornal O Estado de S. Paulo, março 24, p. 6.

Taunay, Afonso d'Escragnolle. 1946. Guia do Museu Republicano "Convenção de Itu”. São Paulo: Indústria Gráfica Siqueira.

Taunay, Afonso d'Escragnolle. 1981. Relatos Monçoeiros. Belo Horizonte: Itatiaia.

Taunay, Alfredo d'Escragnolle. 1875. “Esboço da Viagem Feita pelo Sr. Langsdorff ao Interior do Brasil, desde setembro de 1825 até março de 1829. Escripto em Original Francez pelo $2^{\circ}$ Desenhista da Commissão Scientifica Hercules Florence. Traduzido por Alfredo d'Escragnolle Taunay." Revista do Instituto Histórico e Geográfico Brasileiro, parte primeira: 337-469, parte segunda: 231-302.

Zemella, Mafalda. (1951) 1990. O Abastecimento da Capitania de Minas Gerais no século XVIII. 2. ed. São Paulo: Hucitec. 
Zequini, Anicleide. 2003. “O Sobrado da Convenção em Itu na Antiga Rua do Carmo (atual Rua Barão do Itaim): Uma Pesquisa Documental." Anais do Museu Paulista: História e Cultura Material 10/11 (1): 197-211.

\section{NOTAS}

1. O Museu Paulista é um museu especializado em história da cultura material da sociedade brasileira. Reúne um acervo com cerca de 100 mil objetos e imagens, $200 \mathrm{~m}$ lineares de documentação textual e cerca de 69 mil livros e periódicos do século XVI ao século XX. A partir de 1963, o museu passou a integrar a Universidade de São Paulo. Desde 2013, encontra-se fechado para restauro e reforma.

2. Os bandeirantes eram homens que chefiavam incursões temporárias no interior da América Portuguesa, a partir da capitania de São Paulo, cujo principal propósito era capturar indígenas para o trabalho cativo nas vilas paulistas ou para a sua comercialização com outras regiões da colónia. Com maior ocorrência ao longo do século XVII e inícios do século XVIII, as bandeiras de apresamento de mão de obra, de prospeção mineral e de criação de gado foram em parte responsáveis pelo alargamento dos limites da capitania paulista (Santos 2009).

3. Este artigo apresenta os resultados obtidos durante a pesquisa sobre "A Circulação de Homens e Artefatos na América Portuguesa e a Construção da Memória das Monções". A pesquisa foi financiada pela Fundação de Amparo à Pesquisa do Estado de São Paulo (FAPESP), modalidade "Auxílio à Pesquisa", n.․2018/0331-6.

4. Termo cunhado por Sérgio Buarque de Holanda para se referir aos rios que faziam parte da rota das monções e título de um capítulo do livro Monções da sua autoria (Holanda 1945, 124-184).

5. Desaparecido durante quase um século, o arquivo da expedição Langsdorff só foi reencontrado em 1930 no porão do Museu Botânico do Instituto de Academia de Ciências da Rússia (Chur 1981, 12; Komissarov 2010, 19).

6. Tal diário foi publicado em 1977 pelo Museu de Arte de São Paulo Assis Chateaubriand (MASP) sob o título Viagem Fluvial do Tietê ao Amazonas pelas Províncias Brasileiras de São Paulo, Mato Grosso e Grão-Pará (1825-1829) (Florence 1977), com tradução de Francisco Álvares Machado e Vasconcellos Florence. Em 2018, o Instituto Hercule Florence foi responsável pela publicação de uma nova edição luxuosa do mesmo diário com o seu título original em dois volumes, contendo o fac-símile e a transcrição do documento, textos técnicos e de contextualização, e índices remissivos.

7. $O$ Esboço da Viagem..., traduzido por Alfredo Taunay, seria publicado várias vezes ao longo dos anos sob o título Viagem Fluvial do Tietê ao Amazonas de 1825 a 1829 por várias editoras: Melhoramentos (1941, 1948), Cultrix/Edusp (1977) e Senado Federal (2007).

8. Em correspondência dirigida a Afonso d'Escragnolle Taunay, datada de 13 de setembro de 1920, Alberto Rangel comentou ter encontrado na Biblioteca Nacional de França um álbum de desenhos de Florence, o qual «esta cheio de escorços, tudo por assim dizer inacabado. É bem essa imagem d'essa missão trágica do slavo ensandecido e engulido pelo sertão. Não valerá a pena reprodizil-o todo». Arquivo Permanente do Museu Paulista/Fundo Museu Paulista: Série Correspondências, pasta 112.

9. Em correspondência com Afonso d'Escragnolle Taunay, datada de 10 de agosto de 1920, Benedito Calixto de Jesus afirmava possuir a listagem dos desenhos de Florence «que a familia me fez presente, ha tempos, quando estive em Campinas». Arquivo Permanente do Museu Paulista/ Fundo Museu Paulista: Série Correspondências, pasta 112.

10. «O fato é que as monções de povoado já não pertencem à história das bandeiras. Sem renunciar à existência móvel do bandeirante, os que participam do comércio de Cuiabá e Mato Grosso têm ambições mais disciplinadas» (Holanda 1945, 200-201). 
11. O canoão corresponde à parte mais avançada da dianteira de uma embarcação que media cerca de $14 \mathrm{~m}$, segundo os estudos realizados pelo engenheiro naval Bernardo Andrade e seus alunos de graduação da Escola Politécnica - USP (Borrego et al. no prelo).

12. A ingerência de Afonso d'Escragnolle Taunay com relação às pinturas encomendadas para o Museu foi larga e profundamente estudada por Lima e Carvalho (1993), ao analisarem a recriação do passado colonial paulista por meio de representações pictóricas tendo como matrizes as fotografias da cidade de São Paulo de Militão Augusto de Azevedo (1837-1905) na segunda metade do século XIX. Para o caso das pinturas relacionadas com as monções, ver Oliveira $(2007,87-89)$ e Lima Jr. (2018, 10-14).

13. A clarificação de que se tratava de duas montagens distintas foi identificada pela autora em 2017 no âmbito da preparação da comunicação “Taunay e a Construção da Memória das Monções", apresentada no evento "Affonso de Taunay e o Museu Paulista: Cem Anos de um Projeto de Memória (1917-2017)".

14. Os originais de Hercule Florence encontram-se na posse de Leila Florence, na coleção Cyrillo Hercules Florence, e de Antonio Florence, no Instituto Hercule Florence; o desenho de AiméAdrien Taunay integra a coleção Martha e Erico Stickel, do acervo do Instituto Moreira Salles e a aguarela de Miguelzinho Dutra faz parte do acervo do Museu Republicano de Itu - Museu Paulista - USP. Para o cotejamento de algumas pinturas da Sala das Monções, de 1944, com os originais correspondentes do século XIX utilizados como matriz por Afonso d'Escragnolle Taunay, ver Pardim (2005).

15. Arquivo Permanente do Museu Paulista/Fundo Museu Paulista: Série Correspondências, pasta 190. O facto de Afonso d'Escragnolle Taunay fazer menção à Sala das Monções indica que talvez tenha havido outra criada por ele aquando da desmontagem da exposição da sala A-9 e anterior à inaugurada em 1944, ainda não identificada no Banco de Dados e Imagens do Museu Paulista, nem na documentação textual institucional.

16. «À tardinha, lá pelo ocaso do sol, aproava-se, e então cada remador desempenhava o serviço que lhe havia indicado o guia para toda a viagem. Uns cortavam árvores, limpavam o terreno que ia ser acampamento; outros buscavam lenha seca para acenderem fogo; outros, enfim, armavam as barracas e suspendiam as redes» (Florence 2007, 24).

17. «Nossas cargas foram levadas por terra e as canoas arrastadas até um canal estreito e fundo por cima de baixios, onde os remadores, com água pelo joelho, tinham que retê-las por meio de cabos amarrados à popa» (Florence 2007, 43).

\section{RESUMOS}

$\mathrm{O}$ artigo analisa as formas de apropriação das obras de ilustradores científicos do século XIX produzidas no decurso da expedição Langsdorff (1825-1829) - por Afonso d'Escragnolle Taunay (1876-1958) durante a sua direção no Museu Paulista, em São Paulo (Brasil), e no Museu Republicano Convenção de Itu, uma extensão do Museu Paulista. Afonso d'Escragnolle Taunay, diretor do museu entre 1917 e 1945, ao montar as salas expositivas dedicadas às monções expedições fluviais durante o século XVIII e inícios do século XIX -, acabou não só por obscurecer eventos da expedição Langsdorff retratados pelos ilustradores, como também contribuiu para uma discutível associação entre monções e bandeirantes - expedições de exploração colonial durante o século XVII-XVIII -, cujos movimentos eram distintos em termos de personagens, roteiros e objetivos. Esta associação é uma hipótese que tem sido levantada por vários autores, 
nomeadamente para o caso da exposição inaugurada em 1929 no Museu Paulista. No entanto, este artigo perspetiva uma visão de conjunto, examinando a representação das monções durante a direção de Afonso d'Escragnolle Taunay nos dois museus, em particular as duas exposições no Museu Paulista dedicadas às monções - A-9 (1929) e B-4 (1944) - e no Museu Republicano Convenção de Itu a azulejaria na entrada deste museu. Nos três casos analisa-se a forma como as obras de ilustradores do século XIX, nomeadamente as de Hercule Florence (1804-1879) e de Aimé-Adrien Taunay (1803-1828), foram apropriadas, e em que contexto, para a representação das monções, nomeadamente através da encomenda de pinturas e azulejos.

The article examines the appropriation of nineteenth-century scientific illustrator's works produced during the Langsdorff expedition (1825-1829) - by Afonso d'Escragnolle Taunay (1876-1958) during his time as director of the Museu Paulista in São Paulo (Brazil) and of the Museu Republicano Convenção de Itu, an extension of the Museu Paulista. Afonso d'Escragnolle Taunay, museum director between 1917 and 1945, while organizing exhibition rooms dedicated to the monsoons - river expeditions during the eighteenth and early nineteenth century - not only darkened the Langsdorff expedition's events portrayed by the scientific illustrators, but has also contributed to a doubtful association between monsoons and bandeirantes - expeditions for colonial exploration during the seventeenth and eighteenth century - two movements whose characters, itineraries and objectives were different. This association is a hypothesis raised by several authors, namely regarding an exhibition inaugurated in 1929 at the Museu Paulista. However, this article envisages a more general view, examining the monsoons representation during Afonso d'Escragnolle Taunay management in the two museums, in particular the two exhibitions in the Museu Paulista dedicated to the monsoons - A-9 (1929) and B-4 (1944) - and at the Museu Republicano Convenção de Itu the tiles at the entrance of this museum. In the three cases, it is analysed how the works of nineteenth-century illustrators such as Hercule Florence (1804-1879) and Aimé-Adrien Taunay (1803-1828) were appropriate, and in what context, for the representation of the monsoons.

\section{ÍNDICE}

Keywords: Langsdorff expedition, history of exhibitions

Palavras-chave: Museu Paulista, Museu Republicano de Itu, expedição Langsdorff, Afonso d'Escragnolle Taunay, história das exposições

\section{AUTOR}

\section{MARIA APARECIDA DE MENEZES BORREGO}

Mestre e doutora em História Social pela Faculdade de Filosofia, Letras e Ciências Humanas da Universidade de São Paulo (USP), no Brasil, e pós-doutora em História Social pelo Museu Paulista da USP. Autora dos livros: A Teia Mercantil: Negócios e Poderes em São Paulo Colonial (2010), Códigos e Práticas: O Processo de Constituição Urbana de Vila Rica Colonial (2004) e coautora de Poderes Privados, Práticas Públicas (2002). Docente do Departamento de Acervo e Curadoria do Museu Paulista da USP e do Programa de Pós-graduação em História Social da mesma Universidade. Supervisora técnico-científica do Museu Republicano "Convenção de Itu" e coeditora do periódico Anais do Museu Paulista: História e Cultura Material. Universidade de São Paulo, Museu Paulista, Rua dos Patriotas - lado par, Ipiranga 04207030, São Paulo, Brasil, maborrego@usp.br 